\section{IPR 102 - Dwarf Arabica coffee cultivar with resistance to bacterial halo blight}

\section{Gustavo Hiroshi Sera ${ }^{1 *}$, Tumoru Sera ${ }^{1}$ and Luiz Carlos Fazuoli ${ }^{2}$}

Abstract: 'IPR 102' is a coffee cultivar derivative from a cross between "Catuai" and "Icatu". 'IPR 102' is a dwarf cultivar (medium size) with high rusticity, late ripening cycle, and it is resistant to bacterial halo blight and partial resistant to coffee leaf rust.

Key words: Coffea arabica, breeding, Pseudomonas syringae pv. garcae, rust resistance.

\section{INTRODUCTION}

One of the main challenges of the Brazilian coffee breeding programs is to develop Arabica coffee cultivars with yields higher than the traditional cultivars, such as those of the groups Catuaí and Mundo Novo, which are the most cultivated in Brazil, according to Chalfoun and Reis (2010). Some cultivars have surpassed the yield of cultivars of these two groups in some cultivation environments, such as Catucaí Amarelo 20/15, Sabiá 398, Catiguá MG 02, Catucaí Amarelo 24/137, IPR 103, IPR 100 and Acauã, which had higher yield than Catuaí Vermelho IAC 144 in the northwest region of the state of Rio de Janeiro, Brazil (Rodrigues et al. 2014). Sabiá 398 had higher yield than Catuaí Amarelo IAC 74 in the municipality of Varginha, Minas Gerais, Brazil (Paiva et al. 2010). In a study carried out in four environments in the state of Minas Gerais, it was observed that Sabiá Tardio, Pau Brasil MG1, Obatã IAC 1669-20, Catucaí Amarelo 24/137 and IPR 103 stood out for having the greatest yield, with stability and adaptability, regardless of the environment (Carvalho et al. 2012).

Catuaí and Mundo Novo cultivars have high yield and present wide adaptability in Brazil. However, they are susceptible to leaf rust (Hemileia vastatrix Berk. et $\mathrm{Br}$.) and bacterial halo blight (Pseudomonas syringae pv. garcae), which are two important diseases in coffee crop. The breeding program of the Instituto Agronômico do Paraná (IAPAR) developed the cultivar IPR 102, which presented higher yield than Catuaí Vermelho IAC 81 in different locations of the state of Paraná. In addition to high yield and wide adaptability, IPR 102 is rustic and differs from Catuaí cultivars for being resistant to bacterial blight, and moderately resistant to rust.

\section{PEDIGREE AND IMPROVEMENT METHOD}

'IPR 102' was developed using the pedigree method. It was derivative from a cross between plants of "Catuaí" and "Icatu", carried out at the Instituto Agronômico de Campinas (IAC), in 1972. In 1977, IAPAR introduced the $F_{3}$
Crop Breeding and Applied Biotechnology 17: 403-407, 2017 Brazilian Society of Plant Breeding. Printed in Brazil http://dx.doi.org/10.1590/1984$70332017 v 17 n 4 c 60$

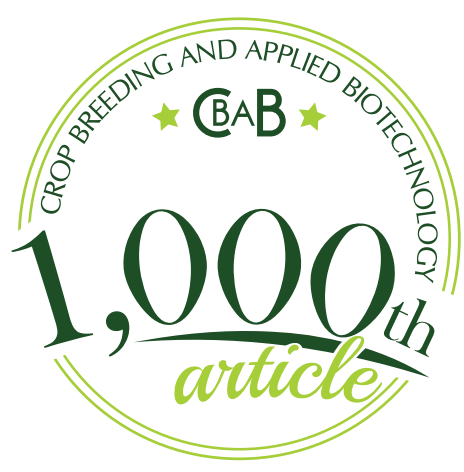

${ }^{1}$ Instituto Agronômico do Paraná (IAPAR), Plant Breeding Department, Rodovia Celso Garcia Cid, km 375, CP 481, 86.047-902, Três Marcos, Londrina, PR, Brazil ${ }^{2}$ Instituto Agronômico (IAC), Centro de Café

"Alcides Carvalho", Av. Dr. Theodureto de Almeida Camargo, 1500, CP 28, 13.012-970, Campinas, SP, Brazil 
generation seeds (IAC H 9878 - EP 187 c.582), named IAPAR 77055. In this $F_{3}$ population, there were plants with large variability for several traits, especially for yield, grain size, leaf size, resistance to bacterial halo blight, and different levels of partial resistance to rust. The intensity of plagiotropic branching and ripening cycle varied little. In the $F_{3}$ and $\mathrm{F}_{4}$ generations, it was selected the plants that presented high yield and resistance to rust and bacterial halo blight. The best $F_{3}$ plant was selected, originating the $F_{4}$ IAPAR 77055-76 line. The plant number 12 of the $F_{4}$ generation was selected, originating the $F_{5}$ IAPAR 77055-76-12 line. This $F_{5}$ line stood out in field trials in different locations of the state of Paraná. Seeds of this $F_{5}$ line were collected to form the seed field of the cultivar IPR 102, which was released in 2015.

\section{PERFORMANCE}

'IPR 102' is recommended for cultivation in both warm and cold regions, with average annual temperatures between 19 ㄷ and 23.5 ㄷ. Y Yeld was evaluated in three field experiments installed in the state of Paraná, in March 2003, in the municipalities of Mandaguari (lat 23 $30.525^{\prime} \mathrm{S}$, long 51 $42.860^{\prime} \mathrm{W}$, alt $655 \mathrm{~m}$ asl), Londrina (lat 23일 22, long 51을 $10^{\prime} \mathrm{W}$, alt $591 \mathrm{~m}$ asl), and Itaguajé (lat $22^{\circ} 37^{\prime} 04^{\prime \prime} \mathrm{S}$, long $51^{\circ} 57^{\prime} 57^{\prime \prime} \mathrm{W}$, alt $349 \mathrm{~m}$ asl), which have average annual temperatures of 20,21 and $23,0 \circ \mathrm{C}$, respectively. The annual relative air humidity is between $75-80 \%$ in Londrina and Mandaguari; and between $65-70 \%$ in Itaguajé. The experiments had the following spacings: $2.5 \times 0.5 \mathrm{~m}$ and $3 \times 0.5 \mathrm{~m}$ in Mandaguari; $2.5 \times 0.5 \mathrm{~m}$ in Londrina; and $3 \times 0.5 \mathrm{~m}$ in Itaguajé. These experiments were carried out in randomized blocks design, with three replications and seven plants per plot. It was applied fungicides for rust control. Fertilization was carried out based on soil analysis and recommendations for the state of Parana. Coffee cherries were harvested and a $2 \mathrm{~kg}$ sample was removed to determine the weight of the green beans. Based on plant spacing, it was calculated the number of plants per hectare, and it was estimated yields in bags of $60 \mathrm{~kg}$ of green beans. ANOVA, Bartlett test of homogeneity of variances, Shapiro-Wilk normality test, and Tukey's test $(p<0.05)$ were performed using the R software version 3.3.0 (R Core Team 2016), package agricolae (Mendiburu 2015).

The main advantage of 'IPR 102' is the high yield, when compared with the traditional coffee cultivars, such as Catuai and IAPAR 59. 'IPR 102' statistically differed from Catuaí and IAPAR 59 in the four environments, except for Mandaguari at spacing of $3 \times 0.5 \mathrm{~m}$, in which IPR 102 did not differ from IAPAR 59 (Table 1). 'IPR 102' mostly stood out in Mandaguari, since at the spacing $2.5 \times 0.5 \mathrm{~m}$, IPR 103 did not differ from IAPAR 59 and Catuaí, while IPR 102 differed from these two cultivars. Moreover, in Mandaguari, at the spacing of $3 \times 0.5 \mathrm{~m}$, IPR 102 had higher yield than 'IPR 103', which is a cultivar with high yield in different cultivation environments of Brazil, in the states of Paraná (Sera et al. 2013), Minas Gerais (Carvalho et al. 2012), and Rio de Janeiro (Rodrigues et al. 2014). In Londrina, IPR 102 did not differ from IPR 103, and in Itaguajé, IPR 103 had higher yield than IPR 102.

'IPR 102' is a dwarf size cultivar, similar to those of the Catuai group, and is recommended for both the low or high tree density planting. The recommended spacing between plants ranges from 0.5 to $0.7 \mathrm{~m}$, depending on the annual average temperature of the cultivation site and on the technologies used, such as fertilizer, irrigation and pruning. In general, this cultivar presents higher yield at spacing of $0.6 \mathrm{~m}$.

The spacing should be chosen based on the size of the farm and on the technology and machinery to be used. Usually, IPR 102 should be planted in a little wider spacing ( 0.25 to $0.5 \mathrm{~m}$ wider) than that of medium size cultivars,

Table 1. Annual average yield per hectare (bags of 60 kg.ha-1) of the 'IPR 102' in comparison with other cultivars (state of Paraná, Brazil)

\begin{tabular}{|c|c|c|c|c|c|c|}
\hline \multirow[b]{2}{*}{ Cultivar $^{1}$} & \multicolumn{5}{|c|}{ Environments $^{2}$} & \multirow[b]{2}{*}{$\%^{6}$} \\
\hline & $\begin{array}{c}\text { Mandaguari } \\
(2.5 \times 0.5 \mathrm{~m})^{3}\end{array}$ & $\begin{array}{c}\text { Mandaguari } \\
(3 \times 0.5 \mathrm{~m})^{3}\end{array}$ & $\begin{array}{c}\text { Londrina } \\
(2.5 \times 0.5 \mathrm{~m})^{4}\end{array}$ & $\begin{array}{c}\text { Itaguajé } \\
(3 \times 0.5 \mathrm{~m})^{5}\end{array}$ & General mean & \\
\hline IPR 102 & $65.62 \mathrm{a}$ & $66.71 \mathrm{a}$ & $69.61 \mathrm{a}$ & $57.86 \mathrm{~b}$ & 64.95 & 132 \\
\hline Catuaí V81 & $42.26 \mathrm{~b}$ & $45.55 \mathrm{~b}$ & $60.23 \mathrm{~b}$ & $49.45 \mathrm{c}$ & 49.37 & 100 \\
\hline IAPAR 59 & $39.81 \mathrm{~b}$ & $52.48 \mathrm{ab}$ & $59.62 \mathrm{~b}$ & $50.22 \mathrm{c}$ & 50.53 & 102 \\
\hline
\end{tabular}

${ }^{1}$ Catuaí V81 = Catuaí Vermelho IAC $81 ;{ }^{2}$ Means followed by the same letter do not differ by the Tukey test ( $\left.<<0.05\right) ;{ }^{3}$ Mean of 6 years of production $(2007,2008,2009$, 2010, 2011, 2012); ${ }^{4}$ Mean of 4 years of production (2007, 2008, 2009, 2010); ${ }^{5}$ Mean of 4 years of production (2006, 2007, 2008, 2009); ${ }^{6}$ Relative yield in percentage based on general mean. 
IPR 102 - Dwarf Arabica coffee cultivar with resistance to bacterial halo blight

such as those of the Catuaí group, since IPR 102 presents lower yield biannuality effects and requires less pruning of the plagiotropic branches.

\section{RESISTANCE TO BACTERIAL HALO BLIGHT}

Bacterial halo blight is an important disease caused by the Pseudomonas syringae pv. garcae (Amaral et al. 1956), which occurs more frequently in crops installed in high altitude regions, with mild temperatures, high rainfall, and which are exposed to strong and or constant winds, and occasional frost (Zoccoli et al. 2011). The disease occurs in the main production regions of Brazil, such as Minas Gerais, São Paulo and Paraná (Mohan 1978, Petek et al. 2006, Ito et al. 2008, Zoccoli et al. 2011) and in other countries such as Kenya (Ithiru et al. 2013).

The use of resistant cultivars is one of the best alternatives for the control of bacterial halo blight. However, there are very few cultivars identified with resistance to this disease. Several authors reported that cultivars of the Catuaí and Mundo Novo groups are susceptibles (Mohan and Pavan 1977, Mohan et al. 1978, Petek et al. 2006, Ito et al. 2008, Zocolli et al. 2011, Andreazi et al. 2015). The cultivars Bourbon Amarelo (Mohan and Pavan 1977), Acaiá Cerrado MG 1474, Topázio MG 1190 (Zocolli et al. 2011), IPR 98, IPR 99, IPR 100, IPR 107 (Ito et al. 2008), and Tupi IAC 1669-33 (Andreazi et al. 2015) were also identified as susceptible.

Resistance to bacterial halo blight was evaluated in three field experiments in the state of Paraná (Brazil), in December 2015, using the cultivars IPR 99, IPR 100 and Catuaí Vermelho IAC 81 as susceptible controls in the experiments 1 and 2 , and only Catuaí Vermelho IAC 81 in the experiment 3. Experiments 1, 2 and 3 were installed at the spacing of $2.5 \mathrm{x}$ $0.6 \mathrm{~m}$, in randomized blocks design, with three replications of five plants per plot, and the first was installed in the city of Congonhinhas, and others in Londrina. In the experiments 1, 2 and 3, the plants were evaluated at 37, 36 and 20 months after planting, respectively. The severity of bacterial halo blight was evaluated in natural infection conditions of the bacterium $P$. syringae pv. garcae, based on the symptoms described by Zambolim et al. (2005), using a scale from 1 to 5 , in which: grade 1 = absence of necrotic lesions; 2 = from 0.01 to $3 \%$ leaves with small necrotic lesions (up to 0.5 $\mathrm{cm}$ ), yellowish halo hardly visible to the naked eye; $3=3.01$ to $15 \%$ leaves with small and medium lesions (up to $1 \mathrm{~cm}$ ), with yellowish halo visible to the naked eye, with the possibility of $1 \%$ of large lesions (more than $1 \mathrm{~cm}$ ); $4=15.01$ to $30 \%$ leaves with small to large lesions; $5=$ more than $30 \%$ of the leaves with small to large lesions, with the possibility of die-back of the branches. In this assessment, it was assessed the leaves from the bottom third to the upper third of the plant, considering the first pair of fully expanded leaves to the tenth pair of fully expanded leaves.

ANOVA, Bartlett test of homogeneity of variances, Shapiro-Wilk normality test, and Tukey's test $(p<0.05)$ were carried out using the R software version 3.3.0 (R Core Team 2016), package agricolae (Mendiburu 2015).

In the three experiments, IPR 102 statistically differed from the susceptible controls, with high resistance level to bacterial halo blight (Table 2). This result corroborates those obtained by lto et al. (2008), who also observed resistance of 'IPR 102' in a field experiment with plants evaluated 10 months after planting.

The cultivar IPR 102 was resistant to bacterial halo blight for the populations of $P$. syringae pv. garcae evaluated on field conditions. Studies with artificial inoculations using populations isolated from different locations should be carried

Table 2. Mean grades of bacterial halo blight severity (BHB) in cultivar IPR 102, when compared with susceptible cultivars evaluated in December 2015, in three field experiments in the state of Parana (Brazil)

\begin{tabular}{|c|c|c|c|c|c|}
\hline \multicolumn{6}{|c|}{ Experiment } \\
\hline \multicolumn{2}{|c|}{$1^{1}$} & \multicolumn{2}{|c|}{$2^{2}$} & \multicolumn{2}{|c|}{$3^{3}$} \\
\hline Cultivar ${ }^{4}$ & $\mathrm{BHB}^{5}$ & Cultivar $^{4}$ & BHB $^{5}$ & Cultivar $^{4}$ & BHB $^{5}$ \\
\hline IPR 99 & $4.50 \mathrm{a}$ & IPR 100 & $4.33 \mathrm{a}$ & Catuaí V81 & $4.20 \mathrm{a}$ \\
\hline Catuaí V81 & $4.47 \mathrm{a}$ & Catuaí V81 & $3.95 \mathrm{a}$ & IPR 102 & $1.07 \mathrm{~b}$ \\
\hline IPR 100 & $4.07 \mathrm{a}$ & IPR 99 & $3.37 \mathrm{a}$ & & \\
\hline IPR 102 & $1.17 \mathrm{~b}$ & IPR 102 & $1.33 \mathrm{~b}$ & & \\
\hline
\end{tabular}

${ }^{1}$ Evaluation carried out at 37 months after planting (Congonhinhas, PR); ${ }^{2}$ Evaluation carried out at 36 months after planting (Londrina, PR); ${ }^{3}$ Evaluation carried out at 20 months after planting (Londrina, PR); ${ }^{4}$ Catuaí V81 = Catuaí Vermelho IAC $81 ;{ }^{5}$ Means followed by the same letter did not differ by the Tukey test at $5 \%$. 
Table 3. Morphological, physiological and agronomic traits of 'IPR 102' with the respective descriptions

\begin{tabular}{|c|c|}
\hline Traits & Descriptions \\
\hline Size (tree height) & Medium ( "Catuaí") \\
\hline Canopy radius & Medium ( “Catuaí") \\
\hline Canopy architecture & Cylindrical ( “Catuaí”) \\
\hline Internode lenght & Medium ( “Catuai") \\
\hline Secondary plagiotropic branching & High ( "Catuaí) \\
\hline Young leaf color & Green and Bronze \\
\hline Color of ripe fruits & Red \\
\hline Fruit shape & Oblong ( "Mundo Novo") \\
\hline Grain lenght & Between short ( “Catuaí") and medium ( "Mundo Novo") \\
\hline Grain width & Between medium ( "Mundo Novo") and large ( "Catuai") \\
\hline Ripening cycle & Late ( "Catuaí") \\
\hline Coffee quality & Similar to "Catuaí" \\
\hline
\end{tabular}

out in order to verify the resistance spectrum of this cultivar.

\section{OTHER TRAITS}

IPR 102 has late ripening cycle, similar to the cultivars of the Catuaí group. In colder regions, with annual average temperatures between $19{ }^{\circ} \mathrm{C}$ and $20.5 \circ \mathrm{C}$, ripening generally occurs between July and August, while in regions with annual average temperature between 20.6 to $22{ }^{\circ} \mathrm{C}$, ripening occurs between June and July. In warmer regions with annual average temperatures between $22.1{ }^{\circ} \mathrm{C}$ and $23.5 \circ \mathrm{O}$, ripening occurs in June. In colder regions, with annual average temperature below 20.5 으, this cultivar is recommended for areas with less risk of frost. The ripening cycle may vary according to the plant spacing used, especially between plants, and to fertilization. Usually, with wider spacing between plants, ripening occurs earlier.

'IPR 102' was moderately resistant to leaf rust (Hemileia vastatrix Berk. et Br.) for the physiological races of the state of Paraná (Sera et al. 2010), and chemical control is usually not necessary. Currently, for the rust races present in Paraná, the resistance level of IPR 102 may vary from moderately susceptible to moderately resistant. The moderately susceptible level may occur if there are environmental factors that favor the increase of rust reproduction, such as moisture excess due to rain and high density plantings, and nutritional aspects of the plant, such as high yield combined with malnutrition. The amount of foliar lesions typical to rust, and defoliation is much lower in this cultivar than in the susceptible cultivars of the Catuaí group and in moderately susceptible cultivars of the Catucaí group.

IPR 102 is susceptible to the nematode Meloidogyne paranaensis, but it has not been evaluated to other nematodes yet.

\section{SEED MAINTENANCE AND DISTRIBUTION}

'IPR 102' is registered by the National Cultivar Registry (Registro Nacional de Cultivares - RNC) of the Ministry of Agriculture, Animal Husbandry and Supply (Ministério da Agricultura Pecuária e Abastecimento - MAPA) under the number 09946, in Brazil. IPR 102 was protected in January 2015 by the Nation Cultivar Protection Service (Serviço Nacional de Proteção de Cultivares - SNPC), in Brazil ( $n$ - 20150127). IAPAR is in charge of the genetic and basic seeds, and private seed producers registered in MAPA are responsible for certified seeds. 
IPR 102 - Dwarf Arabica coffee cultivar with resistance to bacterial halo blight

\section{REFERENCES}

Amaral JF, Teixeira GC and Pinheiro ED (1956) A bactéria causadora da "Mancha Aureolada" do cafeeiro. Arquivos do Instituto Biológico 23: 151-155.

Andreazi E, Sera GH, Faria RT, Sera T, Shigueoka LH, Carvalho FG, Carducci FC and Chamlet D (2015) Desempenho de híbridos F1 de café arábica com resistência simultânea a ferrugem, mancha aureolada e bicho mineiro. Coffee Science 10: 375-382.

Carvalho AM, Mendes ANG, Botelho CE, Oliveira ACB, Rezende JC and Rezende RM (2012) Desempenho agronômico de cultivares de café resistentes à ferrugem no Estado de Minas Gerais, Brasil. Bragantia 71: 481-487.

Chalfoun SM and Reis PR (2010) História da cafeicultura no Brasil. In Reis PR and Cunha RL (eds) Café arábica: do plantio à colheita. U. R. EPAMIG SM, Lavras, p. 21-85.

Ithiru JM, Gichuru EK, Gitonga PN, Cheserek JJ and Gichimu BM (2013) Methods for early evaluation for resistance to bacterial blight of coffee. African Journal of Agricultural Research 8: 2450-2454.

Ito DS, Sera T, Sera GH, Del Grossi L and Kanayama FS (2008) Resistance to bacterial blight in arabica coffee cultivars. Crop Breeding and Applied Biotechnology 8: 99-103.

Mendiburu F (2015) Agricolae: statistical procedures for agricultural research. $\mathrm{R}$ package version 1.2-3. Available at <https://CRAN.Rproject.org/package=agricolae $>$. Accessed on September 5, 2016

Mohan SK and Pavan MA (1977) Resistencia em cultivares e espécies de Coffea à Pseudomonas garcae Amaral et al. Fitopatologia Brasileira 2: 91.

Mohan SK, Cardoso RL and Pavan MA (1978) Resistência em germoplasma de Coffea ao crestamento bacteriano incitado por Pseudomonas garcae Amaral et al. Pesquisa Agropecuária Brasileira 13: 53-64.

Paiva RN, Carvalho CHS, Mendes ANG, Almeida SR, Matiello JB and Ferreira RA (2010) Field performance of coffee progenies (Coffea arabica L.) in Varginha, Minas Gerais State. Coffee Science 5: 49-58.

Petek MR, Sera T, Sera GH, Fonseca ICB and Ito DS (2006) Seleção de progênies de Coffea arabica com resistência simultânea à mancha aureolada e à ferrugem alaranjada. Bragantia 65: 65-73.

R Core Team (2016) R: A language and environment for statistical computing. R Foundation for Statistical Computing, Vienna. Available at <https://www.R-project.org/>. Accessed on September 5, 2016.

Rodrigues LMR, Almeida IMG, Patrício FRA, Beriam LOS, Maciel KW, Braghini MT and Guerreiro Filho O (2013) Mancha aureolada do cafeeiro causada por Pseudomonas syringae pv. garcae. Série Tecnologia Apta. Instituto Agronômico (IAC), Campinas, 24p. (Boletim Técnico IAC 212).

Rodrigues WP, Vieira HD, Barbosa DHSG, Sousa Filho GR and Partelli FL (2014) Agronomic performance of arabica coffee genotypes in northwest Rio de Janeiro State. Genetics and Molecular Research 13: 5664-5673.

Sera GH, Sera T, Fonseca ICB and Ito DS (2010) Resistência à ferrugem alaranjada em cultivares de café. Coffee Science 5: 59-66.

Sera T, Sera GH and Fazuoli LC (2013) IPR 103 - Rustic dwarf arabic coffee cultivar more adapted to hot regions and poor soils. Crop Breeding and Applied Biotechnology 13: 95-98.

Silva MC, Várzea V, Guerra-Guimarães L, Azinheira HG, Fernandez D, Petitot AS, Bertrand B, Lashermes P and Nicole M (2006) Coffee resistance to the main diseases: leaf rust and coffee berry disease. Brazilian Journal of Plant Physiology 18: 119-147.

Zambolim L, Vale FXR and Zambolim EM (2005) Doenças do cafeeiro (Coffea arabica e C. canephora). In Kimati H, Amorim L, Rezende JAM, Bergamin Filho A and Camargo LEA (eds) Manual de fitopatologia. $2^{\text {nd }}$ vol, Agronômica Ceres, São Paulo, p. 165-180.

Zoccoli DM, Takatsu A and Uesugi CH (2011) Ocorrência de mancha aureolada em cafeeiros na Região do Triângulo Mineiro e Alto Paranaíba. Bragantia 70: 843-849. 